\title{
Jovens rurais e as desigualdades sociais do campo representadas no Jornal Nacional
}

\author{
Julia Schnorr
}

\section{SciELO Books / SciELO Livros / SciELO Libros}

SCHNORR, J. Jovens rurais e as desigualdades sociais do campo representadas no Jornal Nacional. In: TRAVANCAS, I., and NOGUEIRA, SG., orgs. Antropologia da comunicação de massa [online]. Campina Grande: EDUEPB, 2016. Paradigmas da Comunicação collection, pp. 69-94. ISBN 978-857879-332-6. Available from SciELO Books $<\underline{\text { http://books.scielo.org }>\text {. }}$

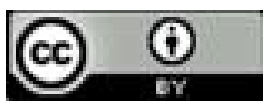

All the contents of this work, except where otherwise noted, is licensed under a Creative Commons Attribution 4.0 International license.

Todo o conteúdo deste trabalho, exceto quando houver ressalva, é publicado sob a licença Creative Commons Atribição 4.0.

Todo el contenido de esta obra, excepto donde se indique lo contrario, está bajo licencia de la licencia $\underline{\text { Creative }}$ Commons Reconocimento 4.0. 


\section{Jovens rurais e as desigualdades sociais do campo representadas no Jornal Nacional}

Julia Schnorr

\section{Introdução}

Os meios de comunicação já estão inseridos no cotidiano da sociedade. Do rádio à comunicação através de telefones móveis, a tendência é a inserção mais profunda em nosso cotidiano, especialmente com as novas plataformas. A geração atual desconhece uma vida sem televisão. Embora existam o telefone celular, smartphones e o computador, a televisão ainda é importante para a conformação de comportamentos e como meio de informação de diversas famílias, em especial no meio rural e na classe popular. Os jovens, seja no campo ou na cidade, cresceram com a assistência da televisão. $O$ que ela ensinou a esses jovens? O eletrodoméstico já ocupou grande parte do lazer dos jovens rurais. $\mathrm{O}$ tempo em família ainda é compartilhado com a assistência da televisão. O que a mídia construiu através do agendamento de notícias sobre o meio rural? E sobre as desigualdades sociais? 
A partir da afirmação de que a mídia tem um papel importante na sociedade, bem como uma possibilidade de agendamento das pautas, o trabalho busca identificar como os jovens leem as notícias sobre as ruralidades no Jornal Nacional, o telejornal com maior audiência no Brasil. Para isso, detemos a atenção na construção das representações midiáticas sobre o modelo de desenvolvimento rural e sobre o pequeno e o grande proprietário. Dessa forma, entrevistamos jovens que moram em localidades rurais de Santa Maria (RS), especificamente aqueles filhos de assentados da reforma agrária ou que estejam envolvidos com grupos de Economia Solidária. Pedro Henrique, 17 anos, é filho de assentados. No mesmo local em que vive, no assentamento Carlos Marighella, cresceram Raimundo e Lúcia, ambos de 18 anos. Já Igor, 17 anos, faz parte de um grupo de Economia Solidária, o Terra Viva.

O Jornal Nacional, programa analisado junto aos jovens, é parte da programação da Rede Globo e centra-se desde 1969, ano de sua construção, como um instrumento de consolidação da unidade nacional. Anderson (2008, p.32), ao utilizar o conceito de comunidade imaginada, referindo-se à nação, afirma que "mesmo os membros da mais minúscula das nações jamais conhecerão, encontrarão, ou sequer ouvirão falar da maioria de seus companheiros, embora todos tenham em mente a imagem viva da comunhão entre eles." Como pontos-chaves da formação da nação, o historiador cita a língua impressa através de livros. Podemos analisar a televisão através desse viés. Quando a Rede Globo inaugurou no Brasil, a integração nacional acabou sendo um dos objetivos do canal. O Jornal Nacional, um dos seus principais programas, foi o carro-chefe.

A partir do momento em que tratamos a televisão sob o aspecto da vida cultural, ou seja, como parte da cultura brasileira, ela torna-se fundamental para compreender a sociedade do país. 
Vizeu (2009, p.77) entende a televisão como um local de referência, como construções didáticas, pois "a televisão na sociedade contemporânea cumpre essa função de reforçar que a realidade existe e que não estamos sozinhos no mundo." Nesse sentido, Maia (2009, p.176) versa sobre as particularidades do telejornalismo em nosso país:

\begin{abstract}
Uma vez encontrado o lugar da TV na vida das pessoas, pensamos também na representação do telejornal para os brasileiros. Dentre uma população com precário hábito de leitura, o noticiário televisivo ganha status de local de orientação, ao qual homens e mulheres recorrem nas sociedades complexas a fim de obter informações para compreender seu cotidiano, seu mundo.
\end{abstract}

A televisão, dessa forma, tem seu lugar na cultura brasileira, com seus produtos trabalhando para a nossa de construção da realidade. Ela é, igualmente, ponto referencial para diversos indivíduos, pois serve como "válvula de escape", conforme apontam os depoimentos que Travancas (2007 apud VIZEU, 2009, p.78) traz:

Não é à toa que alguns comentavam que, embora o jornal mostrasse tragédias e notícias negativas, assistir ele dava uma sensação de tranquilidade. $\mathrm{E}$ comentavam que viam o Jornal Nacional também para relaxar de suas rotinas estressantes e corridas de uma grande metrópole.

Seja como forma de entretenimento, informação ou como referência de orientação, a assistência da televisão é importante no Brasil, pois dá auxílio para compreender de um ponto de vista a realidade do país. Na mídia brasileira, podemos encontrar casos 
em que as classes populares são ridicularizadas ou têm suas vidas particulares expostas, como no Pânico na TV16 e no Programa do Ratinho. Entendemos que as representações midiáticas tornam familiar algo que não costuma ser, como a riqueza para as classes populares e a pobreza para as classes altas. No entanto, Bourdieu (1991, p.448) afirma que as classes dominantes constroem elas mesmas suas representações, fazendo com que os "dominados" fiquem em uma posição de negociação ou resistência simbólica.

Em nossa pesquisa, trabalhamos a desigualdade como portadora de um significado social. Ela não surge naturalmente, não é "inerente à existência da totalidade ou de uma parcela da humanidade em um determinado tempo e lugar; ao contrário, a pobreza é produzida e reproduzida socialmente. "(CAMPOS, 2011, p.51). Por isso, interessa-nos investigar as leituras dos jovens rurais sobre as representações midiáticas da desigualdade social do campo.

\section{Material e métodos}

Temos como amostra inicial quatro jovens que são ou foram moradores e/ou trabalhadores em áreas rurais e que tenham ligações familiares com esse meio, como por meio de familiares. Pedro Henrique, Lúcia e Raimundo cresceram juntos no assentamento Carlos Marighella, a cerca de $12 \mathrm{~km}$ da região central de Santa Maria. Já Igor mora no distrito Arroio Grande, distante $25 \mathrm{~km}$ do centro da cidade.

16 Ressaltamos que Pedro Henrique e Raimundo, dois entrevistados na pesquisa, durante nosso um ano de acompanhamento, modificaram alguns aspectos na assistência televisiva. Não assistem mais ao seu antigo programa favorito, o Pânico na TV, por exemplo. Pedro Henrique afirma que perdeu o interesse após entrar na faculdade e agora mantém uma postura crítica: "deixei de assistir porque só fazem chacota das pessoas, não é legal." 
Para a seleção, o critério foi a assistência frequente da televisão e do Jornal Nacional. Essa escolha foi baseada na experiência de Morley (2001), que realizou um estudo etnográfico de recepção do NationWide em ambientes artificiais e com pessoas que não necessariamente assistiam ao programa. Seu método foi revisado, $\mathrm{e}$ ele afirmou que a assistência em ambientes cotidianos e com receptores familiarizados com os programas é o melhor caminho para a recepção. Dessa forma, realizamos entrevistas semiestruturadas e a entrevista biográfica com os jovens selecionados, sendo que a etnografia foi realizada com todos, salvo com Lúcia ${ }^{17}$, que atualmente não reside em Santa Maria.

Os jovens, que têm idades de 17 e 18 anos, declaram-se estudantes, feirantes e/ou agricultores. A maioria da amostra é composta por homens. A dificuldade em encontrar mulheres jovens que morem no campo corrobora pesquisas que demonstram a masculinização do meio rural (Carneiro, 2005; Weisheimer, 2009). Notou-se que o casamento e o nascimento de um filho, como foi o caso encontrado no assentamento Carlos Marighella, delimita o fim da juventude, já que jovens casados e com filhos não eram indicados quando se questionava para a comunidade em quais famílias se poderia encontrar jovens. Nossa pesquisa objetivou compreender as formações distintas que influenciam na construção de suas leituras, bem como analisar as leituras das desigualdades sociais do campo que os jovens têm da mídia referenciada.

Dividimos nossa investigação com os jovens em três momentos, sendo eles a pesquisa da história de vida, a assistência do telejornal em suas residências, com ou sem seus familiares, adequando-se ao ritmo cotidiano dos jovens, e, por fim, a assistência de vídeos selecionados sobre temáticas relacionadas às desigualdades

17 Nome fictício. 
sociais e ruralidades, tema em que se encaixam as notícias sobre os movimentos sociais. Não houve sequência determinada, realizamos as entrevistas de acordo com a disponibilidade dos jovens e a necessidade da investigação. Os momentos de entrevistas se mesclaram ao de observação participante, ocorrendo, também, as conversas informais com os pais e os moradores mais antigos das localidades.

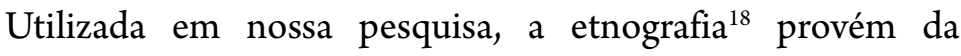
Antropologia e assumiu importância expressiva ao longo dos anos 1980, adquirindo nova abordagem ao ser utilizada em estudos de gênero ou em meios urbanos. A etnografia passou também a ser construída para sua utilização nos estudos da mídia, empregada na recepção especialmente como "uma forma de interpretação que pretende aguçar nossa sensibilidade para os detalhes de como as pessoas lidam com a televisão em seus cotidianos [tradução nossa]" (ANG, 1991 apud DROTNER, 1994, p.395).

O cotidiano é a força motriz para a etnografia, já que possibilita fornecer detalhes e construir subjetividades e características da ordem do abstrato. $\mathrm{O}$ ato de assistir à televisão, que tem fortes vínculos no dia a dia e por várias vezes está incluído nas atividades rotineiras das pessoas, está relacionado ao cotidiano: “Televisão é a vida cotidiana. Para estudar um, temos que estudar ao mesmo tempo o outro [tradução nossa]” (SILVERSTONE, 1989, apud, DROTNER, 1994, p.345).

18 Em nossa pesquisa, utilizamos a etnografia crítica da recepção. Denominamos o método como crítico, porque ele dá atenção, como aponta Ronsini (2007), também à reprodução social, e não somente à criatividade e à resistência dos receptores. A mesma autora, em seu livro "Mercadores de sentido: Consumo de mídia e identidades juvenis" afirma que esse pensamento é construído a partir da "apreensão do sentido possível que os atores sociais dão às práticas sociais e culturais produzidas na relação com os meios de comunicação tecnológicos.” (RONSINI, 2007, p.77) 
Através do contato estabelecido com esses jovens e suas famílias, assim como acompanhando a assistência da televisão, observando a lida no campo e o estar em casa, buscamos entender as particularidades e vivências de cada indivíduo, interpretando a partir disso o significado da mídia para os receptores:

El hogar o la família, insertos en un ambiente social y cultural más amplio, proporcionan, con sus pautas de interacción cotidiana, con sus propios sistemas internos de relaciones, y su própia cultura de legitimación y de formación de la identidade, un laboratorio para la investigación naturalista del consumo y la producción de sentido. (MORLEY, 1992, p. 263)

Nas análises de recepção, a etnografia obteve importância especialmente por relativizar as assertivas da crítica ideológica, na qual houve a "desmitificação" do poder dos meios sobre a audiência. No entanto, Escosteguy (2001, p.42-3) pondera essa afirmativa, pois crê que:

Ao operar no ponto de encontro onde determinadas condições sociais transformam-se em condições especificamente vividas, trabalha-se por dentro de fronteiras. Nesse estreito espaço, de difícil acesso, corre-se o risco permanente de celebrar as resistências ao reconhecer que as audiências respondem ativamente às formas culturais massivas, principalmente, se for levado em consideração o trabalho anteriormente executado de "desmistificar, denunciar e condenar" o poder dos meios sobre a audiência.

Dessa forma, consideramos que o receptor estabelece uma relação ativa com os textos midiáticos, mas não buscamos uma 
vinculação esperançosa de autonomia, ou uma euforia com a vitalidade das audiências, para citar Escosteguy (2001, p.44). Nesse caso haveria uma submissão das relações de poder, o que não concordamos. Assim, falar em mediação e etnografia não significa entrar diretamente no debate da recepção ativa.

Ao total, foram realizados trinta encontros com os quatro jovens, sendo alguns com suas famílias, outros somente com o entrevistado. As entrevistas foram realizadas em suas residências, algumas na varanda, outras na sala ou na cozinha. Seguidamente os pais apareciam e ouviam alguns minutos da entrevista, mas não interferiram efetivamente.

Acompanhamos as feiras livres, aos sábados pela manhã, no Centro de Referência de Economia Solidária Dom Ivo Lorscheiter. Lá era o local onde a família de Igor comercializava seus produtos. Inicialmente minha presença parecia ser um incômodo, especialmente para os jovens. Os pais tinham mais iniciativa para falar comigo. Após algumas semanas de observação participante, as conversas tornaram-se corriqueiras, especialmente após minha apresentação aos curiosos, como os amigos das famílias e os clientes mais assíduos. Essas atividades ocorreram antes das entrevistas e da assistência ao telejornal nas residências, mas continuaram de forma mais esparsa após os encontros em suas residências. No assentamento, enquanto esperávamos os jovens chegarem do trabalho ou da escola, houve uma aproximação do cotidiano familiar, além da possibilidade de questionar os pais sobre a história da família e do assentamento.

Para trabalhar com os jovens, também selecionamos algumas matérias relacionadas às desigualdades sociais do campo. A seleção desse material visou contemplar algumas categorias trabalhadas na pesquisa, sendo elas: agronegócio, agricultura familiar, homem do campo, transgenia e movimentos sociais. Esses vídeos foram assistidos 
em suas residências, em horário acordado entre pesquisador e entrevistado.

\section{Resultados e discussão}

O meio rural foi o principal carro chefe do projeto desenvolvimentista do país, gozando de especial atenção até o início do século $\mathrm{XX}$, quando da ascensão da urbanização e da industrialização. Prova disso é que, nos séculos anteriores, as casas do campo eram mais bem cuidadas que as da cidade, o que representa uma forma de distinção e status. No decorrer do século XX, os parâmetros mudaram. $\mathrm{O}$ centro de desenvolvimento focou-se no meio urbano e o campo foi relegado à sua função extrativista e agrícola. O meio rural como modo de vida (Wanderley, 1999) passa a entrar em crise. Às representações do meio rural como um lugar tranquilo e sossegado (Williams, 1989), somam-se aquelas do atraso.

Hoje, pensar nas ruralidades pode significar sossego para muitas pessoas. No entanto, há outras significações para os trabalhadores do campo. Para os jovens da amostra, falar sobre o rural é versar sobre o trabalho pesado e que, por vezes, exercem desde tenra idade; é ver o trabalhador como um guerreiro, mas também como um sofredor; é afirmar que são diferentes em relação ao jovem que cresceu na cidade, ao mesmo tempo em que não percebem diferenças gritantes entre o meio urbano e o rural, especialmente porque sua conjuntura possibilita transpassar as fronteiras culturais entre o campo e a cidade. Além disso, pensar no meio rural, para esses jovens, é falar sobre planos para a propriedade ou, de uma forma saudosista, contar como era a vida com as famílias que deixaram "para fora" antes de se mudarem para o meio urbano em busca de realização pessoal, educação e emprego. As representações sobre o meio rural são diversas, bem como os modos de vivenciar esse espaço. 
O mundo rural não gera notícias recorrentes no Jornal Nacional. A distância das rotinas jornalísticas e do próprio mundo de vida dos profissionais da informação colabora para que as matérias priorizem o meio urbano. Devemos lembrar, ainda, que de acordo com o último censo, a população brasileira é mais urbanizada que há 10 anos. Já em 2000, 81\% dos brasileiros viviam em áreas urbanas; e, em 2010, esse número aumentou para $84 \%$. De acordo com observação do telejornal realizada pela pesquisadora durante os meses de outubro de 2011 a fevereiro de 2012, as matérias sobre ruralidades versaram, em sua maioria, sobre economia agrícola, em especial àquela relacionada ao mercado exportador. Há matérias, também, sobre secas e enchentes. $\mathrm{O}$ mundo rural referindo-se a um espaço de vida e de reprodutividade social é pouco mostrado no Jornal Nacional.

Fernandes (2010, p.189), ao falar sobre a mídia brasileira - e ele engloba a Rede Globo, o jornal Folha de São Paulo e a revista Veja -, afirma que tenta-se impedir que a realidade do campo brasileiro apareça como de fato é: uma das estruturas fundiárias mais concentradas do mundo e ainda em processo de intensificação dessa desigualdade rural." Para o autor, a mídia colabora mostrando os conflitos, mas não explica o motivo de existirem, focando os problemas nos movimentos camponeses, como o MST.

Para Campos (2011, p.109), os grupos de comunicação difundiram a concepção de que a produção de alimentos em grande escala é sinônimo de agronegócio. A generalização do termo faz considerar as iniciativas produtivas agroindustriais ou agropecuárias como agronegócio, quando podem ser ao contrário. Os agricultores que consomem insumos e têm maquinários pesados em suas propriedades não necessariamente estão alinhados a esse modelo de desenvolvimento rural.

O uso de agrotóxicos continua sendo um assunto polêmico para os jovens. Os pequenos agricultores buscaram, ao longo dos anos, 
uma proposta de diferenciação com alimentos orgânicos e agroecológicos. Dessa forma, a produção generalizada com agrotóxicos é rechaçada. Os jovens, ao assistirem às notícias sobre a utilização do agrotóxico, referem-se ao produto como um "veneno". Percebe-se que o agrotóxico não é "somente" um elemento químico. Para os jovens, a opinião sobre os agrotóxicos se amparam na ideologia fornecida pelos movimentos sociais. Outro jovem destaca que os produtores que desejam parar de utilizar o produto terão dificuldades para trabalhar com a commodity, pois as sementes já estão acostumadas: "como é que agora eles vão fazer para poder segurar a produção sem esse veneno? Com certeza vai dar muito mais trabalho para eles."

A relação do agrotóxico com a saúde também é lembrada. Um rapaz questiona os motivos que fizeram com que o produto fosse proibido nos Estados Unidos, como foi mostrado em uma reportagem do Jornal Nacional: "será que pra lá (Estados Unidos) não está fazendo mal para que eles retirem (de circulação)?” Por anos a família do jovem Igor trabalhou com plantação de fumo, como diversas outras pequenas propriedades na Quarta Colônia ${ }^{19}$. Essa produção é conhecida historicamente por sua dependência de agrotóxicos que, por vezes, acabam afetando a saúde dos agricultores. Esse frequente uso causou problemas de saúde em seu pai, e a mudança para a hortifruticultura foi essencial para a melhora da sua qualidade de vida. Sua mãe relatou que se tivessem continuado com a monocultura do fumo, ela teme que seu marido já estivesse morto. A partir da influência familiar, além do conhecimento adquirido nas oficinas de capacitação do projeto Cooesperança/Esperança, Igor tem contato com ideias fortemente contrárias ao uso de agrotóxicos e também à transgenia vegetal.

19 A Quarta Colônia Imperial de Imigração Italiana foi criada em 1877, no Rio Grande do Sul. 
Os jovens leem o Jornal Nacional a partir de seu cotidiano como pequenos agricultores. Para Pedro Henrique, as diferenças se fazem visíveis entre a sua propriedade e aquela que vê nas matérias sobre ruralidades: "faz questão de mostrar o tratorzinho" ou "falou que tem 160 trabalhadores fixos nessa propriedade, imagina." No assentamento, além de não existir mão de obra fixa contratada, o pai de Pedro Henrique trabalha com arado de tração animal, o que é considerado algo penoso e em desuso até mesmo por outros pequenos agricultores. A mecanização no assentamento Carlos Marighella é ínfima.

Ao assistirem a uma matéria sobre os transtornos que a transposição do Rio São Francisco estavam causando às famílias de pequenos agricultores no nordeste brasileiro, Lúcia diz que esses se encontravam "abandonados e piores do que já estavam", ou seja, a condição dos agricultores anteriormente era ruim e, com os transtornos, piorou. Aqui, éimportante ressaltar a categoria de sociabilidade, já que a moça deixou a zona rural, pois a família enfrentava problemas financeiros, principalmente porque seu núcleo familiar era grande e não conseguia cultivar todos os hectares de terra da propriedade que detinha. A situação da família de Lúcia é apontada por Raimundo: "a família dela enfrentava dificuldades, eram em número maior. Foi a única saída [ela sair do meio rural]”. Sobre a matéria do Rio São Francisco, Lúcia complementa, ao afirmar que a população das cercanias aparece como abandonada, que ela fica com a "a sensação de total desleixo do próprio governo."

Igor pensa diferente, pois acredita que os agricultores da matéria que tiveram suas casas danificadas com rachaduras causadas pelas explosões nas construções ganharam indenizações para deixar suas casas e já poderiam ter saído de suas propriedades. 
Os agricultores não saíram, porque não quiseram. Eles (o governo) estão dando indenizações, estão dando tudo para sair. O problema não é do governo, é dos moradores. (Igor, 17 anos, Grupo Terra Viva)

Os agricultores, no período das secas foram buscar emprego nas obras, mas não encontrarem emprego nas construtoras que estão trabalhando na transposição. Para Lúcia, isso mostra claramente a desigualdade social que existe no país. A promessa de progresso que a transposição traria, seja através da irrigação, seja por meio das vagas nas obras, ficou, para a moça, não é uma realidade, também porque as obras estão paradas em diversos lugares. Lúcia afirma:

Os grandes dão pouca ou quase nenhuma importância à sociedade da classe baixa, e que onde poderia dar mais renda e gerar mais empregos foi apenas ilusão para aquele povo. (Lúcia, 18 anos, assentamento Carlos Marighella)

Todos os jovens da amostra garantem que no Jornal Nacional são veiculadas mais notícias sobre agronegócio do que são apresentadas matérias relacionadas à agricultura familiar. Um dos motivos citados pelos jovens é que "a agricultura familiar não é uma coisa que dê muito dinheiro". Outro jovem aponta que "nunca falam do homem do campo". Um filho de assentado conta que o Jornal Nacional não mostra o pequeno produtor, mas sim aquele que já está estruturado

$\mathrm{O}$ pequeno agricultor, com uma hortinha de 50 por 30, com um canteiro de alface, um de cenoura, um de beterraba, não vai ter, não vai mostrar isso. Gostaria que mostrassem no Jornal Nacional, mas 
não vão. (Pedro Henrique, 17 anos, assentamento Carlos Marighella)

Para os jovens, o telejornal mostra o homem do campo como um sofredor, seja quando está em extrema seca ou quando sofreu com as enchentes. Guerreiro ou alguém que venceu as intempéries climáticas: essas são algumas características que os jovens dão para o homem do campo. A identidade social desse morador é ser um trabalhador do campo. O rural está ligado ao trabalho agrícola. Assim, os jovens concordam com a leitura do telejornal, a de que o homem do campo é alguém sofredor, "por causa de todo esse trabalho braçal que tem", diz Pedro Henrique. Raimundo também salienta o lado sofrido do homem do campo no Jornal Nacional, pois, para ele, o morador do campo aparece mais na época de apelos climáticos.

Quando aparece ali (no Jornal Nacional), aparece quando a pessoa perde tudo. Nunca ouvi na vida dizer: "Ah! O agricultor está bem de vida porque deu muito lucro na plantação." (Raimundo, 18 anos, assentamento Carlos Marighella)

Igor aponta outro lado. De acordo com ele, o Jornal Nacional prioriza os aspectos positivos do meio rural, não destacando as dificuldades do campo. O jovem cita o exemplo de uma matéria que mostrava a história de vida de uma agricultora familiar que tinha transformado sua vida.

Ela saiu, estava trabalhando numa feira comum, como a minha mãe, que saiu daqui e foi trabalhar numa feira grande. Ela saiu de um agronegócio pequeno que ganhava pouco para ganhar bastante. Como vou dizer assim, ganhava, em dinheiro, duzentos reais e foi lá para ganhar mil ou mil e 
pouco, aí ela se desenvolveu, ela foi crescendo mais, tendo mais coisas, entendeu? (Igor, 17 anos, Grupo Terra Viva)

Igor traz o exemplo do telejornal para sua vida pessoal. Sua mãe era empregada doméstica e seu pai trabalhava para uma empresa fumageira. Hoje eles trabalham como feirantes e são reconhecidos, pois trabalham na maior feira de Santa Maria. Para ele, a identificação com a matéria está relacionada com a mudança de vida positiva da família.

\section{O MST e a reforma agrária}

Mais de uma vez, em distintas perguntas, o assunto mídia e MST surgiu nas respostas, em especial com os jovens do assentamento Carlos Marighella. Eles se empolgavam durante suas argumentações, como se esse fosse, também, um momento de direito de resposta. Especialmente aqueles que tinham esse comportamento eram os jovens que haviam vivenciado de forma mais forte o cotidiano de ação do MST, como Pedro Henrique e Lúcia, que viveram respectivamente, por quatro anos corridos e dois anos, com períodos na cidade, em acampamentos. São os jovens, também, que são filhos de atuais ou antigos dirigentes do MST.

De acordo com Fernandes (2010, p. 179), a luta pela terra é um luta territorial e de família, "já que envolve o conjunto de seus membros em diversas atividades." Por mais que somente um dos membros esteja envolvido diretamente com os acampamentos ou ocupações, "a família camponesa toda se envolve na mobilização pela terra, cuidando de várias outras necessidades básicas."

O envolvimento de somente um membro familiar nos acampamentos é o caso da família de Raimundo. Embora isso tenha ocorrido, ele tem uma postura firma em relação às ocupações, o que lhe garante uma leitura de resistência, pois diz que o Jornal 
Nacional mostra os militantes do MST como "pessoas violentas. Isso que eles mostram. Pessoas que invadem tudo quanto é coisa." Não obstante ele tenha algumas críticas internas à política da época do acampamento e ao abandono do movimento social em relação ao assentamento, especialmente após a dissolução da cooperativa que mantinham, Raimundo acredita que o Jornal Nacional deveria mostrar outro lado do MST

Tinha que ter mais informação do que é que é Sem Terra. Eles falam muita coisa dos Sem Terra, não é pouco não. Chamando de ladrão.. esse tipo de coisa. Para falar dos Sem Terra tem que ter mais informação, do que só falar mal. Eu nunca ouvi falar bem dos Sem Terra na TV. Isso eu nunca vi. (Raimundo, 18 anos, assentamento Carlos Marighella)

A crítica dos jovens é que os militantes do MST aparecem como "baderneiros, bagunceiros", dando "a impressão que vão destruir alguma coisa, que vão chegar ali quebrando tudo." Pedro Henrique ressalta que essa é a impressão que o telespectador tem no final da matéria, pois a construção da notícia, ao seu ver, tendencia a notícia à desordem, à violência e à destruição. Para Lúcia, que também tem uma leitura resistente nessa questão, as notícias sobre as manifestações não problematizam o motivo da existência do movimento social, ou seja, a reforma agrária.

Quando estão noticiando sobre o MST, foi sempre quebrando alguma coisa, destruindo alguma coisa ou brigando por alguma coisa. Eu sempre vi isso no Jornal Nacional. No contexto bem em si não é tão mostrado o porquê daquela reforma 
agrária. Mais é mostrado o que eles estão fazendo naquele momento sem ter um antes ou em ter um depois. (Lúcia, 18 anos, assentamento Carlos Marighella)

Igor, que não é ligado ao processo da reforma agrária, afirma que o MST aparece no Jornal Nacional sempre de uma forma violenta, especialmente em suas manifestações. O jovem confirma que não tem nada contra a reforma agrária, mas não é a favor dos métodos do movimento social. Em conversas informais, Igor destaca o medo que tem de sua propriedade, que tem sete hectares, ser visada pelo MST para suas manifestações. Ele afirma que "o MST, ele gosta de caminhar (em referência às marchas). Por que a Dilma não pega um pedaço de terra lá na Amazônia e dá pra eles?"

Querem aumento tudo bem, mas para que fazer toda a destruição que eles fazem em lavouras, tomar lavouras, destruir cercas, fazer tiroteio como aquela vez, quando não sei quantos morreram lá com o tiroteio com a polícia? (Igor, 17 anos, Grupo Terra Viva)

Através da análise dos dados da amostra, percebemos que os jovens da amostra que são filhos de assentados da reforma agrária, ou seja, Pedro Henrique, Lúcia e Raimundo, têm, a partir de suas vivências, tanto no movimento social, quanto na cotidianidade familiar, uma criticidade em relação ao $\mathrm{JN}$ no que se refere à representação do movimento social em suas matérias. O jovem Igor, embora faça parte de um ambiente familiar a favor da reforma agrária e que, por vezes, conviveu com assentados no Feirão Colonial e no projeto Cooesperança/ Esperança, acaba tendo uma leitura contrária ao MST, baseadas especialmente na codificação apresentada pelo Jornal Nacional. 


\section{A pobreza}

Em nosso trabalho, não tratamos a pobreza como se sua existência fosse natural em nossa sociedade. Para nós, as desigualdades são socialmente construídas. Os jovens da nossa amostra são pertencentes à classe popular ${ }^{20}$. Embora sejam proprietários de terra, são pequenos produtores. Produzem hortifruticultura, têm pequenos animais, alguns estão, com a ajuda de programas federais ou municipais, começando a escavação de micro açudes para a produção de peixes. Contudo, as famílias fazem parte da massa trabalhadora agrícola que não emprega mão de obra assalariada e que envolve o âmbito familiar em sua administração e trabalho cotidiano. $\mathrm{O}$ auxílio à produção agrícola de alguns membros da família podem não ser, também, remunerados. ${ }^{21}$

A resistência da representação da pobreza no Jornal Nacional é majoritária em nossa amostra. Todos os jovens discordam da maneira como o pobre é mostrado no telejornal. De maneira geral, os jovens afirmam que a miserabilidade e a vulnerabilidade dessa classe são as principais características apresentadas pela classe popular no Jornal Nacional. Para Lúcia, o telejornal apresenta a pobreza como algo negativo, o que ela discorda

20 Como lembra Hall (2006, p.245), o termo "popular" guarda relações muito complexas com o termo "classe". Hall (2006, p.241) tem como definição do termo popular "as formas e atividades cujas raízes se situam nas condições sociais e materiais de classes específicas; que estiveram incorporadas nas tradições e práticas populares”. A sua definição do popular está em relação contínua com as classes dominantes, seja de antagonismo, influência ou relacionamento, mas não existem "'culturas" inteiramente isoladas e paradigmaticamente fixadas, numa relação de determinismo histórico, a classes "inteiras" - embora existam formações culturais de classe bem distintas e variáveis.” (HALL, 2006, p.245)

21 Quadros, Waldir; Maia, Alexandre. Estrutura Sócio-Econômica do Brasil. Revista Economia Contemporânea, Rio de Janeiro, v. 14, n. 3, p. 443-468, set./dez. 2010 
É mais ou menos assim: ser pobre não é defeito. $\mathrm{Eu}$ acho que eu também sou pobre e não me arrumo mal assim. Ser pobre não é defeito, acho que não tem muita diferença. Só um pouco de menos luxo... um pouco menos de luxo. Não tem muita diferença. (Lúcia, 18 anos, assentamento Carlos Marighella)

Os jovens propõem que o telejornal mostre outro lado da vida das classes populares. Uma classe mais festiva, que foque mais no em seu cotidiano: "Ele vai para o trabalho, foi cansativo, voltou pra casa, vai tomar o chimarrão dele, vai conversar com a mulher dele. Não é totalmente bom ou totalmente ruim, tem um meio termo."

Raimundo, mesmo sendo filho de assentados, não é envolvido com o MST. Muito menos gosta de política. No entanto, sente em seu cotidiano as diferenças de classe. Para ele, pobres e ricos vivem em situação antagônica. É evidente a apropriação do conceito de identidade de classe através de vivências de seus pais, em especial no mundo do trabalho, em padarias, na fábrica e em obras de construção civil. O jovem citou o exemplo do pai de seu de colega de escola que trabalhou 15 anos em uma empresa e foi demitido. Para o jovem, isso causa grande revolta:

Todo rico que começa a enriquecer, enriquece em cima de pobres. Os ricos não valorizam os pobres. Eles fazem as pessoas trabalhar, trabalhar, trabalhar, e quando estão bem, mandam eles embora. Ali no Distrito Industrial tem vários exemplos. O pai trabalha ali e conhece bem. Se as pessoas vão procurar emprego aqui e não dão, vão encontrar aonde? (Raimundo, 18 anos, assentamento Carlos Marighella) 
Igor, ao contrário dos outros, tem uma visão distante da desigualdade social, uma vez que diz não percebê-la no seu dia a dia. Afirma ter realizado um trabalho para o colégio sobre a temática, e que encontrou diversos sites sobre o assunto na internet, mas que não sabe falar sobre o tema. No entanto, o jovem não nega a desigualdade, ele sabe que existe, percebe no seu cotidiano, mas não pensa sobre o assunto, não tem criticidade. Não faz, por exemplo, a inter-relação da realidade de pequenos agricultores com a dos latifundiários, bem como a realidade das concentrações urbanas abordadas em telejornais. Quando questionado sobre o que poderia ser realizado para diminuir a desigualdade social em nosso país, o jovem demonstra distância e pouca reflexão em sua resposta

Não sei. Não trabalho com vida social. Não sei, pior que não sei mesmo. Não presto atenção nisso aí, né. (Igor, 17 anos, Grupo Terra Viva)

\section{Alguns apontamentos}

Os entrevistados utilizados para construção deste artigo, Igor, Pedro Henrique, Lúcia e Raimundo, têm matrizes parecidas. Embora discordem em diversas situações, os jovens concordam que o desenvolvimento rural no país enfrenta problemas com o latifúndio e o uso de agrotóxicos. A mediação família e movimento social, permeadas pela classe social, são fundamentais para entender as leituras das representações midiáticas. As histórias de vida dos jovens ajudam a explicar a leitura da mídia realizada pelos jovens. Por vezes, suas famílias foram oprimidas pela dependência de empresas fumageiras, no caso de Igor, ou por realmente não terem acesso à terra, no caso dos jovens envolvidos com o MST. A opressão os acompanhou em suas vidas. 
De modo geral, os jovens idealizam o meio rural como um local pacífico e com qualidade de vida, apresentando como aspectos negativos a falta de transporte público e privado, bem como a falta de lazer, saúde, comunicação e educação. No entanto, percebemos que Igor (Ecosol) e Pedro Henrique (Carlos Marighella) têm projetos de vida que mesclam o meio rural e o urbano. São esses jovens que mais circulam entre os dois espaços - para estudo, trabalho e lazer - e fazem planos para suas vidas de modo que se interliguem o campo e a cidade, caracterizando o que Carneiro (2005) chama de novas fronteiras culturais rural-urbanas.

Os jovens da amostra estão inseridos no contexto das transformações que o país vive nos últimos tempos. Partícipes da nova classe média, as famílias dos jovens estão cada vez mais inseridas na sociedade de consumo. Essa inserção é conquistada a um alto custo, como extensas horas de trabalho, além de, por vezes, enfrentarem o preconceito de classe que diferencia na vida prática a classe média tradicional e a nova classe trabalhadora. A nova classe média da amostra é a favor da transferência de renda condicionada do governo federal, e a maioria dos jovens participa do programa Bolsa Família, tendo uma leitura de resistência sobre a codificação proposta pelo Jornal Nacional.

O momento do telejornal é de encontro familiar. Após um dia de trabalho e estudo, essa é a hora de reunião, de contar o que ocorreu na jornada. As intimidades, por vezes, competem com o volume do som da televisão. Se a história que o familiar tem a contar é mais interessante que a matéria do Jornal Nacional, os olhos se deslocam da televisão e acompanham a narrativa do momento, que é, dependendo da família, de confraternização. Independente disso, constatamos que o momento reúne famílias.

Percebemos que, ao contrário do rechaço maior que há em relação ao agrotóxico, as matérias sobre transgênicos apresentaram 
maior aceitação nos entrevistados. Leituras negociadas foram encontradas em Lúcia e em Raimundo, mas por motivos distintos. Lúcia destaca a produtividade do transgênico, enquanto Raimundo perde-se nas explicações, afirmando ser "coisa de Sem Terra" ser contra transgênico. Pedro Henrique e Igor, mais próximos de movimentos sociais, mantêm suas posições de resistência, sendo contrário à utilização do transgênico. Para os jovens que têm leituras resistentes, a agroecologia e o uso de defensivos naturais são o caminho para um desenvolvimento rural sustentável.

Outra temática que encontramos resistência é a representação da pobreza no JN. Os jovens discordam sobre como as classes populares estão representadas no telejornal, em especial sobre o enfoque na miserabilidade em que se encontram. Pedro Henrique, Raimundo e Igor confirmam que o Jornal Nacional prioriza o aspecto ruim de ter menos dinheiro e Lúcia acredita que ser pobre não é defeito.

Todos os jovens assentados são contrários às representações do MST no telejornal, sendo que Raimundo e Pedro Henrique criticaram alguns aspectos desse movimento social. Igor tem uma leitura alinhada à codificação dominante do Jornal Nacional, acreditando que os militantes fazem atos violentos e truculentos. Consideramos que ser jovem oriundo da agricultura familiar e relacionado a movimentos sociais, seja em prol da reforma agrária ou da economia solidária, não garante a criticidade do jovem em relação à mídia e nem seu envolvimento político em organizações civis. As leituras são decorrentes da mediação de classe, do histórico de vida, do envolvimento familiar no movimento social e da experiência escolar. Entre o ficar e o sair do meio rural, os jovens decidem-se entre a realização pessoal e a dependência financeira dos pais, que ainda ocorre em boa parte da amostra. 
A criticidade em relação aos meios de comunicação, que é bandeira dos movimentos sociais trabalhados, é um dos pontos a serem fortalecidos ou desenvolvidos nos discursos dos jovens. Pedro Henrique é o que apresenta maior criticidade, pois faz ponderações em relação aos telejornais e, de maneira geral, não confia nos meios de comunicação. $\mathrm{O}$ jovem diz que "por um lado talvez essas informações que eles passam não condizem com a verdade, né." Já Igor tem uma visão ingênua da televisão, pois confia nos programas televisivos e acredita que é um meio de comunicação para informar a população, "para a gente saber, né". Raimundo confia só em alguns programas de televisão, sendo que o Jornal Nacional é um deles. Lúcia diz que os telejornais são fontes de informação confiáveis, porque têm um grande público de assistência e, para ela, seria difícil enganar um grande público. Os jovens criticam algumas matérias, em especial suas representações, mas em geral confiam na qualidade técnica do telejornalismo, o que tem auxílio na credibilidade jornalística que o JN construiu nos últimos anos.

Para os jovens, embora assistam e tenham assistido durante muitos anos ao Jornal Nacional, eles são veementes em dizer que o programa não tem importância no cotidiano. Alguns apontam que há necessidade de se ter um filtro das informações para assistir ao Jornal Nacional, mas, em geral, afirmam que não faz diferença no dia a dia. Os jovens, no entanto, não têm uma variedade de acessos a informações jornalísticas que não sejam esse telejornal. Travancas (2007) afirma que para camadas populares a televisão é um veículo de informação fundamental. No caso, quanto menos condições sociais uma família tiver, mais difícil é o acesso à pluralidade de informações. Às vezes a única fonte de informação jornalística é o Jornal Nacional. Embora possam assistir a outros canais de televisão, como SBT, Band e Record, é válido 
problematizar aqui a diversidade editorial da chamada "grande mídia” brasileira. O quanto difere as notícias jornalísticas desses canais de televisão pública?

\section{Referências}

ANDERSON, Benedict. Comunidades imaginadas: reflexões sobre a origem e a difusão do nacionalismo. São Paulo: Companhia das Letras, 2008.

BOURDIEU, Pierre. La distinción - criterios y bases sociales del gusto. Madrid: Taurus, 1991.

CAMPOS, Christiane. A face feminina da pobreza em meio à riqueza do agronegócio: trabalho e pobreza das mulheres em territórios do agronegócio no Brasil: o caso de Cruz Alta-RS. Buenos Aires: CLACSO, 2011.

CARNEIRO, Maria José. Juventude Rural: Projetos e Valores. In: ABRAMO, Helena; Branco, Pedro. Retratos da juventude brasileira: análises de uma pesquisa nacional. Fundação Perseu Abramo: São Paulo, 2005, p.243-26.

DROTNER, Kirsten. Menos é mais: estudos etnográficos de mídia e seus limites. In: LOPES, Maria Immacolata V. de. Temas contemporâneos em comunicação. São Paulo: Edicon/Intercom, 1997.

ESCOSTEGUY, Ana Carolina D. Cartografias dos estudos culturais: uma versão latino-americana. ed. On-line. Belo Horizonte: Autêntica, 2001. (Coleção Estudos culturais; 8). Disponível em: $<$ http://identidadesculturas.files.wordpress.com/2011/05/ 
cartografias-dos-estudos-culturais-uma-versc3a3o-latino-americana. pdf $>$.

FERNANDES, Bernardo. Formação e territorialização do MST no Brasil. In: CARTER, Miguel (org.). Combatendo a desigualdade social - O MST e a reforma agrária no Brasil. São Paulo: Editora UNESP, 2010.

HALL, Stuart. Da diáspora - identidades e mediações culturais. Belo Horizonte: Editora UFMG, 2006.

MAIA, Aline. Televisão, telejornalismo e juventude: o que jovens da periferia pensam sobre o Jornal Nacional? Estudos em jornalismo e mídia. v.6, n. 2, p. 175 - 188 jul./dez. 2009.

MINAYO, M.C.S. O desafio do conhecimento. São Paulo: Hucitec. 1999. 269 p.

MORLEY, David. Depoimento de David Morley a Ana Carolina Escosteguy. In: Cartografias dos Estudos Culturais: uma versão latino-americana. Belo Horizonte: Autêntica, 2001. p.249-268.

QUADROS, Waldir; MAIA, Alexandre. Estrutura socioeconômica do Brasil. Revista Economia Contemporânea. Rio de Janeiro, v. 14, n. 3, p. 443-468, set./dez. 2010

RONSINI, Veneza. Mercadores de sentido: Consumo de mídia e identidades juvenis. Porto Alegre: Sulina, 2007.

TRAVANCAS, Isabel. Juventude e televisão. Rio de Janeiro: FGV, 2007. 
VIZEU, Alfredo. O telejornalismo como lugar de referência e a função pedagógica. Revista FAMECOS. Porto Alegre, n. 40, 2009.

WANDERLEY, Maria de Nazareth. O mundo rural como um espaço de vida: reflexões sobre a propriedade da terra, agricultura familiar e ruralidade. Porto Alegre: Editora da UFRGS, 2009.

WEISHEIMER, Nilson. A situação juvenil na agricultura familiar. 2009, 320 f. Tese (Doutorado em Sociologia) - Programa de Pós-Graduação em Sociologia da UFRGS. Porto Alegre: UFRGS, 2009. Disponível em: < http://www.lume.ufrgs.br/bitstream/handle $/ 10183 / 15908 / 000693991 . p d f$ ? sequence $=1>$

WILLYAMS, Raymond. Campo e a cidade na história e na literatura. Trad. por Paulo Henrique de Britto. São Paulo: Cia das Letras, 1989. 